\title{
Karakteristik Kuantitatif dan Jarak Genetik Beberapa Galur Ayam Lokal
}

\section{Quantitative Characteristics and Genetic Distance of Some Local Chicken Strains}

\author{
Asa B.S.R.N. Putri, Gushairiyanto dan Depison* \\ Program Studi Peternakan Fakultas Peternakan Universitas Jambi \\ Jl. Raya Jambi - MA. Bulian KM 15 Mendalo Indah Jambi 36361 Indonesia
}

Article history

Received: May 20, 2020;

Accepted: Nov 19, 2020

* Corresponding author:

E-mail:

depison.nasution@unja.ac.id

DOI:

10.46549/jipvet. v11i2.110

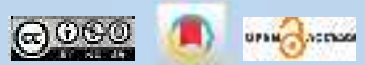

\begin{abstract}
The research of this study aims to know quantitative characteristics and genetic distance of several local chicken strains. The research material is Super chicken, KUB chicken, and Kampung chicken. The method used was an experiment with a sample of 82 chickens from each strain. Retrieval of BW and AVG data are collected every month until the age of 2 months, while body measurements are taken at the age of 2 months. The data collected are quantitative characteristics includes body weight, weight gain, beak length, beak width, head length, head circumference, head height, neck length, neck circumference, wing length, back length, back height, back height, chest length, chest width, shank length, shank circumference, tibia length, tibia circumference, third finger length and pubic bone distance. Data collected were analyzed using t-test to see the difference in BB, PBB, and body measurements using Minitab statistical software 18. Mahalanobis distance approach with a matrix of variance between variables based on chicken strains was arranged into a matrix to determine the discriminant function and then form phylogenetic trees by using the MEGA X program via the UPGMA method. Body weight, average daily gain, and body sizes of Super chickens are bigger than other strains of chickens, while the smallest is owned by Kampung chickens. The closest genetic distance matrix was shown by Super chickens to KUB chickens (4.08) and the farthest genetic distance was shown by KUB chickens to Kampung chickens (13.87).
\end{abstract}

Keywords: Genetic distance; Local chicken; Quantitatif characteristic

\section{Abstrak}

Tujuan penelitian ini untuk mengetahui karakteristik kuantitatif dan jarak genetik beberapa galur ayam lokal. Materi penelitian ini adalah ayam Super, ayam KUB, dan ayam Kampung. Metode yang digunakan adalah eksperimen dengan sampel 82 ekor ayam jantan/betina yang dipelihara umur 1 hari sampai umur 2 bulan pada masing-masing galur. Pengambilan data BB dan PBB diambil pada setiap bulan hingga ayam berumur 2 bulan, sedangkan ukuran-ukuran tubuh diambil pada umur 2 bulan. Data yang dihimpun adalah karakteristik kuantitatif meliputi bobot badan, pertambahan bobot badan, panjang paruh, lebar paruh, panjang kepala, lingkar kepala, tinggi kepala, panjang leher, lingkar leher, panjang sayap, panjang punggung, tinggi punggung, panjang dada, lebar dada, panjang shank, lingkar shank, panjang tibia, lingkar tibia, panjang jari ketiga dan jarak tulang pubis. Data yang dikumpulkan dianalisis menggunakan uji-t untuk melihat perbedaan $\mathrm{BB}, \mathrm{PBB}$, dan ukuran-ukuran tubuh menggunakan perangkat lunak statistika Minitab 18. Pendekatan jarak Mahalanobis dengan matriks peragam antara peubah berdasarkan galur ayam disusun menjadi sebuah matriks untuk mengetahui fungsi diskriminan kemudian membentuk pohon filogenetik dengan menggunakan program MEGA X melalui metode UPGMA. BB, PBB, dan ukuran-ukuran tubuh ayam Super lebih besar dibandingkan dengan galur ayam lainnya, sedangkan yang paling kecil dimiliki oleh ayam Kampung. Nilai matrik 
jarak genetik terdekat ditunjukkan oleh ayam Super dengan ayam KUB $(4,08)$ dan jarak genetik terjauh ditunjukkan oleh ayam KUB dengan ayam Kampung $(13,87)$.

Kata kunci: Ayam lokal; Jarak genetik; Karakteristik kuantiatif

\section{PENDAHULUAN}

Ayam lokal merupakan salah satu jenis ternak unggas yang dapat dimanfaatkan sebagai penghasil protein hewani. Ayam lokal memiliki kelebihan mudah beradaptasi dengan lingkungan, tahan terhadap lingkungan yang buruk dan lebih kebal terhadap penyakit apabila dibandingkan dengan ayam ras (Nataamijaya, 2010). Beberapa galur ayam lokal adalah ayam Super, ayam KUB dan ayam kampung lokal.

Ayam Super adalah hasil persilangan jantan ayam Kampung berpostur besar dan berkualitas baik dengan ayam betina ras petelur. Pada umur 8 mingggu ayam Super mampu mencapai bobot 900-1.100 gram/ekor dan mulai bertelur pada umur 20 minggu (Ashar et al., 2016). SK Menteri Pertanian Nomor :274/Kpts/SR.120/2/2014 telah menetapkan galur ayam KUB sebagai salah satu galur ayam hasil pemuliaan ayam Kampung (Gallus-gallus domesticus) yang telah diseleksi selama 6 generasi, produksi telurnya mampu mencapai 160-180 butir/tahun. Ayam Kampung adalah ayam lokal yang tidak memiliki karakteristik khusus, namun mudah dikenali karena banyak dipelihara di desa-desa hampir di seluruh wilayah Indonesia. Ayam Kampung memiliki peranan yang cukup besar bagi kehidupan masyarakat terutama yang berada di pedesaan untuk memenuhi kebutuhan proten hewani (daging dan telur) maupun tambahan penghasilan (Inggriani et al., 2020). Apabila dibandingkan dengan ayam ras, Produktivitas ayam Lokal masih tergolong rendah. Salah satu usaha untuk meningkatkan produktivitas ayam Lokal dapat dilakukan dengan perbaikan mutu genetik melalui seleksi atau persilangan yang diawali dengan melakukan karakterisasi.

Karakterisasi adalah langkah awal yang dilakukan dalam pemuliabiakan ternak dalam rangka mengidentifikasi sifat-sifat penting yang bernilai ekonomis atau merupakan penciri rumpun yang bersangkutan. Karakterisasi dapat diketahui dengan cara mengidentifikasi karakteristik kuantitatif berupa bobot badan dan ukuran-ukuran tubuh pada ternak. Ukuranukuran tubuh tersebut meliputi panjang badan, panjang/tinggi leher, panjang sayap, lebar sayap, lebar dada, panjang kepala, panjang paruh, panjang tulang tibia, panjang metatarsus, lingkar metatarsus, panjang jari terpanjang, panjang fermur, panjang sternum, dan bobot badan (Ashifudin et al., 2017; Hummairah et al., 2016; Rangkuti et al., 2016). Data tersebut dapat digunakan untuk mengidentifikasi penciri ternak untuk memprediksi potensi produksi, peluang peningkatan produktivitas ternak, sebagai acuan standarisasi ternak secara lengkap serta menganalisis jarak genetik (Chamdi, 2005). Sampai saat ini informasi mengenai sumberdaya genetik ayam buras masih sedikit diketahui guna kepentingan perbaikan mutu genetik, oleh karena itu dilakukan penelitian mengenai karakteristik kuantitatif dan jarak genetik beberapa galur ayam lokal.

\section{MATERI DAN METODE}

Lokasi penelitian ini di Farm Fakultas Peternakan Universitas Jambi yang dilaksanakan selama 2 bulan dimulai dari Agustus-Oktober 2019.

\section{MATERI}

Materi pada penelitian ini adalah 82 ekor dari masing-masing galur ayam lokal, timbangan digital dengan kapasitas $3 \mathrm{~kg}$ ketelitian 0,1 gr dan alat tulis.

\section{METODE}

Pengamatan secara langsung terhadap bobot badan dan ukuran-ukuran tubuh pada ternak ayam. Ayam yang diamati adalah ayam yang dipelihara mulai DOC sampai umur 2 bulan dengan sistem pemeliharaan di dalam kandang koloni dengan pemberian pakan komersial dan air minum yang tersedia setiap saat (ad libitum). Setiap galur berada di kandang yang berbeda dengan ukuran kandang panjang $\mathrm{x}$ lebar $\mathrm{x}$ tinggi adalah $4 \times 3 \times 1,8 \mathrm{~m}$ yang 
dilengkapi dengan tempat pakan dan minum serta lampu. Penimbangan bobot badan dilakukan pada setiap bulan, sedangkan pengukuran karakteristik kuantitatif dilakukan pada bulan ke-2. Setiap ternak ayam yang timbang dan diukur diberi tanda nomor di sayap.

Data yang dihimpun adalah karakteristik kuantitatif berdasarkan penelitian Putri et al. (2020) yang meliputi:

1. Bobot Badan (BB) dengan cara menimbang ayam dengan timbangan digital $(\mathrm{g})$.

2. Pertambahan Bobot Badan (PBB) selisih bobot badan akhir dengan bobot badan awal (BB 1 bulan - BB DOC dan BB 2 bulan BB 1 bulan) (g)

3. Panjang Paruh (PP) jarak antara pangkal maxilla sampai ujung maxilla, diukur menggunakan jangka sorong digital (mm).

4. Lebar Paruh (LP) diukur dari pinggir paruh bagian luar sebelah kiri dan kanan, dengan menggunakan jangka sorong digital ( $\mathrm{mm}$ ).

5. Panjang kepala (PK) diukur dari pangkal paruh hingga kepala bagian belakang, menggunakan jangka sorong digital (mm).

6. Lingkar kepala (LK) diukur pada bagian kepala yang paling tinggi dengan melingkarkan pita ukur (cm dikonversikan ke mm).

7. Tinggi Kepala (TK) diukur pada bagian kepala yang paling tinggi dengan menggunakan jangka sorong digital ( $\mathrm{mm}$ ).

8. Panjang Leher (PL) diukur dari tulang first cervical vetebrae sampai dengan last cervical vetebrae menggunakan jangka sorong digital (mm).

9. Lingkar Leher (LL) melingkarkan pita ukur dileher (cm dikonversikan ke $\mathrm{mm}$ ).

10. Panjang Sayap (PSa) diukur dari tulang humerus sampai ujung phalanges menggunakan pita ukur (cm di konversikan ke $\mathrm{mm})$.

Keterangan:

$$
\mathrm{R}=\frac{\overrightarrow{x^{-}}}{x^{-j}}, \text { Kemudian } \mathrm{K}=\mathrm{R} .\left(\mathrm{X}_{1.1 \mathrm{j}}, \mathrm{X}_{1.2 \mathrm{j}}, \ldots \mathrm{Xn} \cdot \mathrm{nj}\right)
$$

$\mathrm{R}=$ rataan antar jenis kelamin

$\overline{\mathrm{x}} \mathbf{1}=$ rataan pada data jantan

$\overline{\mathrm{xj}} \quad=$ rataan pada data betina

$\mathrm{K}=$ Koreksi

$\mathrm{x} 1.1 \mathrm{j}=$ data baris pertama pada kolom pertama ayam berjenis kelamin betina
11. Panjang Punggung (PPu) di ukur dari pangkal leher sampai pangkal ekor menggunakan pita ukur (cm di konversikan ke $\mathrm{mm}$ ).

12. Tinggi Punggung (TPu) di ukur dari bagian bawah ayam berpijak sampai punggung menggunakan penggaris $(\mathrm{cm} \quad \mathrm{di}$ konversikan ke mm).

13. Panjang Dada (PD) pengukuran panjang dada (sternum) dilakukan dari ujung dada bagian depan sampai ujung bagian belakang menggunakan jangka sorong $(\mathrm{mm})$.

14. Lebar Dada (LD) Pengukuran lebar dada diperoleh dengan mengukur jarak dari tulang sternum bagian kiri hingga bagian kanan (yang paling lebar) menggunakan jangka sorong digital (mm).

15. Panjang Shank (PS) diukur sepanjang tulang tarsometatarsus (shank) menggunakan jangka sorong digital ( $\mathrm{mm}$ ).

16. Lingkar Shank (LS) melingkari pita ukur pada bagian tengah tulang tarsometatarsus (shank) (cm di konversikan ke mm).

17. Panjang Tibia (Pti) diukur dari patella sampai ujung tibia diukur dengan menggunakan jangka sorong digital ( $\mathrm{mm})$.

18. Lingkar Tibia (Lti) melingkarkan pita ukur pada tibia ( $\mathrm{cm}$ di konversikan ke $\mathrm{mm}$ ).

19. Panjang Jari Ketiga (PJK) diukur dari pangkal sampai ujung jari ketiga di ukur menggunakan jangka sorong digital ( $\mathrm{mm}$ ).

20. Jarak Tulang Pubis (JTP) diukur menggunakan jangka sorong digital (mm).

\section{ANALISIS DATA}

Data yang telah dikumpulkan meliputi bobot badan dan ukuran-ukuran tubuh dikelompokkan berdasarkan jenis kelamin, selanjutnya dikoreksi ke ukuran-ukuran jantan dengan mengikuti penelitian Depison (2010) sebagai berikut: 
Kemudian dianalisis dengan menggunakan uji F lalu uji t Pengolahan data dibantu dengan menggunakan perangkat lunak statistika Minitab versi 18.

Fungsi diskriminan digunakan untuk mengetahui persentase kesamaan dan jarak genetik beberapa galur ayam lokal. Hasil analisis diskriminan digunakan untuk menentukan jarak genetik yang akan membentuk pohon filogenetik dengan menggunakan program MEGA X melalui metode UPGMA (Unweighted Pair Group Method with Arithmetic) (Tamura et al., 2013). Jarak genetik minimum menurut (Nei, 1987) dihitung dengan menggunakan rumus:

$$
D^{2}{ }_{(i, j)}=\left(\bar{x}_{l}-\bar{x}_{j}\right) C^{-1}\left(\bar{x}_{l}-\bar{x}_{j}\right)
$$

$\nu^{2}(\hat{t}, j)=$ nilai statistik Mahalanobis sebagai ukuran jarak kuadrat genetik antar kelompok ayam lokal ke-i dan kelompok ayam lokal ke-j;

$C^{-1} \quad=$ kebalikan matrik gabungan ragam peragam antar peubah;

$\bar{x}_{l} \quad=$ vektor nilai rerata pengamatan dari kelompok ayam lokal ke-i pada masing masing peubah kuantitatif; dan

$\bar{x}_{j} \quad=$ vektor nilai rerata pengamatan dari kelompok ayam lokal ke-j pada masing-masing peubah kuantitatif.

Analisis statistik Mahalanobis dilakukan dengan menggunakan paket program statistik Minitab versi 18 (Triyanto, 2009).

\section{HASIL DAN PEMBAHASAN}

\section{BOBOT BADAN}

Tabel 1 menunjukkan bahwa bobot DOC, bobot 1 dan 2 bulan tertinggi hingga terendah berturut-turut adalah ayam Super, ayam KUB dan ayam Kampung, artinya ayam Super memiliki bobot badan paling tinggi dibandingkan dengan ayam KUB maupun ayam kampung. Berdasarkan uji-t, bobot DOC ayam Super berbeda nyata $(\mathrm{P}<0,05)$ dengan ayam KUB maupun ayam Kampung, dan ayam KUB berbeda nyata dengan ayam Kampung.
Pada umur 1 bulan, bobot ayam Super berbeda nyata $(\mathrm{P}<0,05)$ dengan ayam KUB maupun ayam Kampung, namun ayam KUB berbeda tidak nyata $(\mathrm{P}>0,05)$ dengan ayam Kampung. Pemeliharaan umur 2 bulan menunjukkan bahwa bobot ayam Super berbeda nyata $(\mathrm{P}<0,05)$ dengan ayam KUB maupun ayam Kampung, dan ayam KUB berbeda nyata $(\mathrm{P}<0,05)$ dengan ayam Kampung. Kondisi ini menunjukkan bahwa ayam super memiliki bobot yang paling baik dibandingkan ayam KUB maupun ayam Kampung. Hal ini sesuai dengan pendapat Ashar et al. (2016) bahwa ayam Super memiliki bobot badan yang relatif lebih tinggi dibandingan dengan ayam lokal lainnya.

Tabel 1. Bobot badan (g) berapa galur ayam lokal

\begin{tabular}{|l|c|cc|}
\hline \multirow{2}{*}{\multicolumn{1}{c}{ Ayam Lokal }} & \multicolumn{3}{c}{ Umur } \\
\cline { 2 - 4 } & DOC & 1 Bulan & 2 Bulan \\
\hline Ayam Super & $40,03 \pm 3,51^{\mathrm{a}}$ & $349,47 \pm 35,38^{\mathrm{a}}$ & $837,98 \pm 68,97^{\mathrm{a}}$ \\
\hline Ayam KUB & $34,20 \pm 3,09^{\mathrm{b}}$ & $235,64 \pm 38,63^{\mathrm{b}}$ & $713,15 \pm 66,75^{\mathrm{b}}$ \\
\hline Ayam Kampung & $26,38 \pm 1,70^{\mathrm{c}}$ & $224,68 \pm 41,09^{\mathrm{b}}$ & $605,53 \pm 80,01^{\mathrm{c}}$ \\
\hline
\end{tabular}

Keterangan: Superskrip huruf yang berbeda pada kolom yang sama berarti berbeda nyata $(\mathrm{P}<0,05)$

Rataan bobot badan umur 2 bulan pada ayam kampung Super hasil penelitian ini lebih rendah dari bobot standar yaitu 900-1.100 gram (Ashar et al., 2016), bobot badan ayam KUB pada penelitian ini lebih tinggi dari penelitian Urfa et al. (2017), yaitu 512 gram, sedangkan bobot badan ayam kampung hasil penelitian ini lebih tinggi dari hasil penelitian Kurnia (2011),

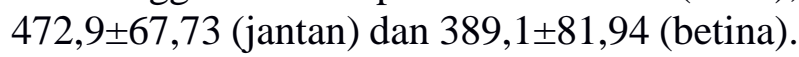
Perbedaan ini diduga karena adanya perbedaan genetik, karena keseragaman lingkungan sudah diupayakan sehingga keragaman lingkungan dapat diabaikan. Hal ini sesuai dengan pendapat Subekti dan Arlina (2011) bahwa perbedaan 
bobot badan dapat disebabkan oleh faktor genetik, kondisi lingkungan dan manajamen pemeliharaan

\section{PERTAMBAHAN BOBOT BADAN}

Gambar 1 dapat dilihat bahwa terjadi peningkatan bobot badan seiring dengan pertambahan umur ayam. Pertambahan bobot badan merupakan respon dari kemampuan ternak ayam dalam mencerna makanan. Ayam Super memiliki PBB yang paling tinggi apabila dibandingkan dengan ayam KUB maupun ayam Kampung baik pada pengukuran pertama dan kedua. pada pengukuran pertama, PBB ayam KUB dan ayam Kampung terlihat hampir sama, namun PBB ayam KUB, baik pada pengukuran pertama maupun kedua lebih tinggi dibandingkan ayam Kampung. Hal ini menunjukkan bahwa pada umur 1-2 bulan PBB ayam KUB lebih tinggi dibandingan dengan ayam Kampung. Hal ini sesuai dengan pendapat Urfa et al. (2017) bahwa sampai umur 12 minggu ternak ayam masih memiliki laju pertumbuhan cenderung naik.

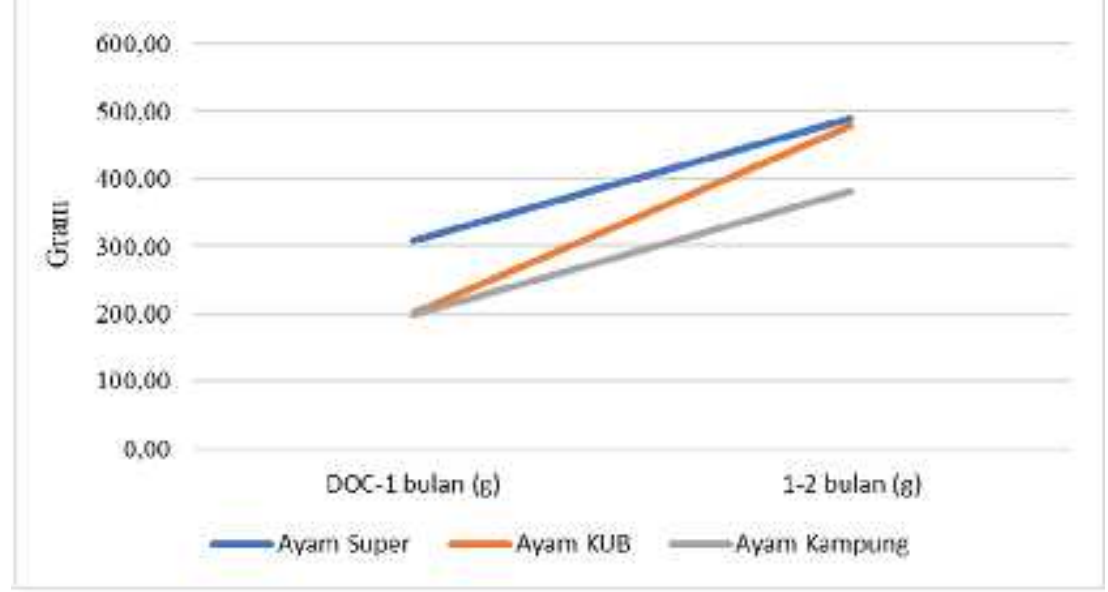

Gambar 1. Grafik pertambahan bobot badan beberapa ayam lokal sampai umur 2 bulan

Berdasarkan Gambar 1 dapat dilihat pula bahwa ayam Super memiliki pertumbuhan yang paling baik dibandingkan dengan ayam KUB maupun ayam Kampung, yang artinya bahwa galur ternak dapat mempengaruhi pertumbuhan. Hal ini sesuai dengan pendapat Bell dan Weaver (2002) bahwa faktor yang mempengaruhi pertumbuhan adalah galur ayam, jenis kelamin, dan faktor lingkungan.

\section{KARAKTERISTIK KUANTITATIF}

Berdasarkan Tabel 2. Menunjukkan dari semua ukuran-ukuran tubuh yang diukur terlihat bahwa ukuran tubuh yang berbeda nyata $(\mathrm{P}<0,05)$ antara ayam Super dengan ayam KUB adalah LP, PK, TK, LK, Psa, TPu, PD, LS, Lti, PJK, dan JTP, sedangkan PP, PL, LL, PPu, LS, PS, dan Pti berbeda tidak nyata $(P>0,05)$. Ukuran-ukuran tubuh antara ayam Super dengan ayam Kampung berbeda nyata $(\mathrm{P}<0,05)$ pada semua ukuran tubuh yang di ukur. Ukuran-ukuran tubuh antara ayam KUB dengan ayam Kampung yang berbeda nyata $(\mathrm{P}<0,05)$ adalah PP, TK, PL, Psa, PPu, PD, LD,
PS, LS, Pti, Lti, PJK, sedangkan LP, PK, LK, $\mathrm{LL}, \mathrm{TPu}$, dan JTP berbeda tidak nyata $(\mathrm{P}>0,05)$. Dari semua ukuran-ukuran tubuh yang diukur terlihat bahwa ukuran tubuh yang berbeda nyata $(\mathrm{P}<0,05)$ antara ayam Super, ayam KUB dengan ayam Kampung adalah TK, Psa, PD, LS, Lti dan PJK yang artinya terdapat perbedaan penambahan ukuran tulang TK, Psa, PD, LS, Lti, dan PJK pada masing-masing galur ayam lokal. Perbedaan ukuran-ukuran tubuh pada penelitian ini diduga disebabkan oleh faktor genetik, karena faktor lingkungan sudah diupayakan seragam. Hal ini sesuai dengan pendapat Hikmawaty et al. (2014) yang menyatakan bahwa ukuran tubuh ternak dapat berbeda antara satu sama lain yang kemungkinan adanya perbedaan keragaman tersebut disebabkan potensi genetik, lokasi asal, sistem pemeliharaan dan perkawinan yang diterapkan di daerah tersebut.

Secara umum rataan ukuran-ukuran tubuh paling besar dimiliki ayam Super, sedangkan rataan ukuran tubuh paling kecil dimiliki oleh 
ayam Kampung. Ayam Super memiliki ukuran tubuh lebih tinggi dibandingkan dengan ayam KUB maupun ayam Kampung, hal ini menunjukkan bahwa ayam kampung Super memiliki kemampuan produksi daging dan kerangka tubuh lebih tinggi pula daripada ayam KUB maupun ayam Kampung. Ayam KUB memiliki rataan ukuran tubuh lebih tinggi dibandingkan dengan ayam Kampung lokal, artinya kemampuan produksi daging dan kerangka tubuh ayam KUB lebih tinggi daripada ayam Kampung, maka dari itu kemampuan produksi daging dan kerangka tubuh paling rendah terdapat pada ayam Kampung. Berdasarkan hasil ini, terlihat bahwa ukuran tubuh pada ternak dapat mempengaruhi kemampuan produksi daging. Hal ini sesuai dengan pendapat Rajab dan Papilaya (2012) bahwa ukuran tubuh memiliki kaitan erat dengan produktivitas, terutama sifat bobot badan pada ternak ayam.

Tabel 2. Rataan ukuran-ukuran tubuh ayam Super, ayam KUB dan ayam kampung

\begin{tabular}{lccc}
\hline \multicolumn{1}{c}{ Ukuran Tubuh } & Ayam Super (mm) & Ayam KUB (mm) & Ayam Kampung (mm) \\
\hline Panjang Paruh (PP) & $30,88 \pm 2,58^{\mathrm{a}}$ & $28,92 \pm 1,42^{\mathrm{a}}$ & $27,08 \pm 1,65^{\mathrm{b}}$ \\
Lebar Paruh (LP) & $6,36 \pm 0,91^{\mathrm{a}}$ & $5,59 \pm 0,44^{\mathrm{b}}$ & $5,33 \pm 0,72^{\mathrm{b}}$ \\
Panjang Kepala (PK) & $39,08 \pm 3,05^{\mathrm{a}}$ & $37,06 \pm 1,84^{\mathrm{b}}$ & $36,32 \pm 2,67^{\mathrm{b}}$ \\
Tinggi Kepala (TK) & $30,74 \pm 2,17^{\mathrm{a}}$ & $27,54 \pm 1,94^{\mathrm{b}}$ & $26,07 \pm 1,27^{\mathrm{c}}$ \\
Lingkar Kepala (LK) & $101,98 \pm 6,29^{\mathrm{a}}$ & $98,78 \pm 6,02^{\mathrm{b}}$ & $94,46 \pm 4,71^{\mathrm{b}}$ \\
Panjang Leher (PL) & $107,39 \pm 6,77^{\mathrm{a}}$ & $106,37 \pm 6,57^{\mathrm{a}}$ & $96,49 \pm 6,36^{\mathrm{b}}$ \\
Lingkar Leher (LL) & $79,37 \pm 6,77^{\mathrm{a}}$ & $77,68 \pm 6,53^{\mathrm{ab}}$ & $74,95 \pm 5,35^{\mathrm{b}}$ \\
Panjang Sayap (Psa) & $170,08 \pm 8,49^{\mathrm{a}}$ & $166,07 \pm 6,67^{\mathrm{b}}$ & $129,88 \pm 5,71^{\mathrm{c}}$ \\
Panjang Punggung (PPu) & $167,20 \pm 8,05^{\mathrm{a}}$ & $165,29 \pm 6,01^{\mathrm{a}}$ & $160,93 \pm 6,27^{\mathrm{c}}$ \\
Tinggi Punggung(TPu) & $216,78 \pm 8,06^{\mathrm{a}}$ & $206,05 \pm 6,08^{\mathrm{b}}$ & $203,80 \pm 6,31^{\mathrm{b}}$ \\
Panjang Dada (PD) & $106,10 \pm 6,98^{\mathrm{a}}$ & $100,54 \pm 5,23^{\mathrm{b}}$ & $95,08 \pm 6,34^{\mathrm{c}}$ \\
Lebar Dada (LD) & $49,79 \pm 5,51^{\mathrm{a}}$ & $47,47 \pm 4,37^{\mathrm{a}}$ & $41,25 \pm 5,41^{\mathrm{b}}$ \\
Panjang Shank (PS) & $64,96 \pm 7,37^{\mathrm{a}}$ & $62,76 \pm 6,25^{\mathrm{a}}$ & $58,39 \pm 6,46^{\mathrm{b}}$ \\
Lingkar Shank (LS) & $41,31 \pm 3,85^{\mathrm{a}}$ & $36,44 \pm 2,38^{\mathrm{b}}$ & $34,10 \pm 3,19^{\mathrm{c}}$ \\
Panjang Tibia (Pti) & $100,35 \pm 7,88^{\mathrm{a}}$ & $97,76 \pm 6,61^{\mathrm{a}}$ & $90,45 \pm 6,72^{\mathrm{b}}$ \\
Lingkar Tibia (Lti) & $90,73 \pm 9,39^{\mathrm{a}}$ & $78,66 \pm 6,16^{\mathrm{b}}$ & $72,66 \pm 6,03^{\mathrm{c}}$ \\
Panjang jari Ketiga (PJK) & $54,78 \pm 5,42^{\mathrm{a}}$ & $52,11 \pm 4,49^{\mathrm{b}}$ & $48,26 \pm 5,13^{\mathrm{c}}$ \\
\hline Jarak Tulang Pubis (JTP) & $13,98 \pm 0,82^{\mathrm{a}}$ & $13,60 \pm 0,58^{\mathrm{b}}$ & $13,34 \pm 0,68^{\mathrm{b}}$ \\
\hline
\end{tabular}

Keterangan: Superskrip huruf yang berbeda pada baris yang sama untuk masing-masing jenis ayam berarti berbeda nyata $(\mathrm{P}<0,05)$,

\section{JARAK GENETIK}

Berdasarkan fenogram (Gambar 2) ayam Kampung menunjukkan garis yang berbeda dengan ayam Super dan ayam KUB, yang mengartikan hubungan kekerabatan ayam Kampung dengan ayam Super maupun ayam KUB cukup jauh berdasarkan ukuran dan bentuk tubuh, hal ini dipengaruhi tidak adanya campuran galur lain terhadap ayam Kampung. Secara genetik ayam Kampung bertipe kecil sedangkan ayam Super dan ayam KUB bertipe besar menandakan berbeda secara genetik sehingga jarak genetiknya relatif jauh. Jarak genetik ayam Kampung dengan ayam Super 10,47 sedangkan ayam Kampung dengan ayam
KUB 13,87. Untuk galur ayam Kampung jika disilangkan dengan ayam Super atau ayam KUB dapat diperoleh peningkatan ukuran tubuh dikarenakan jauhnya jarak genetik tersebut. Hal ini didukung oleh pendapat Pinem et al. (2015), bila persilangan dilakukan pada ternak yang memiliki jarak genetik yang relatif jauh maka akan mendapatkan kemajuan ukuran kuantitatif.

Pohon fenogram menunjukkan bahwa galur ayam Super lebih dekat dengan ayam KUB dibandingkan dengan ayam Kampung berdasarkan ukuran dan bentuk tubuh. Hal ini diduga karena ayam Super dan ayam KUB sudah mengalami proses peningkatan mutu genetik yaitu persilangan pada ayam Super dan 
proses seleksi pada ayam KUB yang menjadikan ukuran tubuh yang dimiliki oleh kedua ayam ini relative lebih besar dibandingkan dengan ayam Kampung yang menyebabkan jarak genetik pada ayam Super dan ayam KUB relative lebih dekat. Hubungan kekerabatan yang dekat terjadi pada galur ayam Super dengan ayam KUB $(4,08)$. Hal ini menunjukkan apabila dilakukan persilangan antara ayam Super dan ayam KUB tidak akan mendapatkan kemajuan ukuran kuantitatif (heterosis). Hal ini sesuai dengan pendapat Pinem et al. (2015), bila persilangan akan dilakukan pada ternak yang memiliki jarak genetik yang dekat tidak akan mendapatkan kemajuan ukuran kuantitatif yang mengesankan apabila tidak disertai dengan seleksi yang ketat.

Tabel 3. Jarak genetik antar galur ayam

\begin{tabular}{cc|cc}
\hline Galur & Super & KUB & Kampung \\
\hline Super & 0 & & \\
KUB & 4,08 & 0 & \\
Kampung & 10,47 & 13,87 & 0 \\
\hline
\end{tabular}

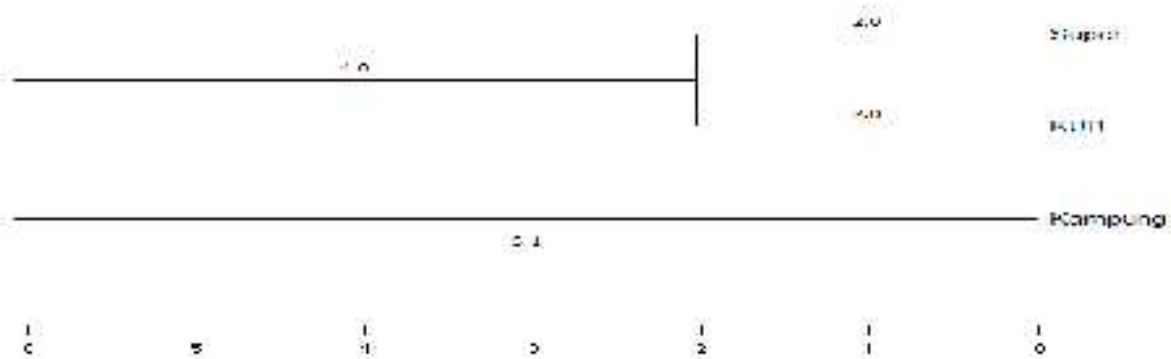

Skala jarak genetik ayam berdasarkan morfometrik

\section{Gambar 2. Pohon fenogram ayam}

Hubungan kekerabatan yang ditunjukkan oleh pohon fenogram memperjelas bahwa adanya usaha yang dilakukan untuk peningkatan mutu genetik baik melalui cara persilangan (ayam Super) maupun melalui cara seleksi (ayam KUB) akan berpengaruh terhadap kedekatan hubungan kekerabatan pada ternak dan memberikan gambaran memiliki tujuan produksi yang hampir sama, seperti yang terlihat dengan hubungan kekerabatan ayam Super dekat dengan ayam KUB yang mempunyai tujuan produksi yang sama berupa hampir menuju ke type pedaging.

\section{KESIMPULAN}

Bobot badan, pertambahan bobot badan dan ukuran tubuh terbaik dimiliki oleh ayam Super. Hubungan kekerabatan yang dekat terjadi pada galur ayam Super dengan ayam KUB dibandingkan dengan hubungan kekerabatan pada ayam Super dengan ayam Kampung maupun ayam ayam KUB dengan ayam Kampung. Adanya usaha yang dilakukan untuk peningkatan mutu genetik baik melalui persilangan maupun seleksi akan berpengaruh terhadap kedekatan hubungan kekerabatan

\section{DAFTAR PUSTAKA}

Ashar MA, Pagala dan Saili T. 2016. Karakteristik fenotip kualitatif ayam kampung super. Jurnal Ilmu Peternakan Halu Oleo. 1(1):1-9.

Ashifudin MI, Kurnianto E dan Sutopo. 2017. Karakteristik morfometrik ayam kedu jengger merah dan jengger hitam generasi pertama di satker ayam MaronTemanggung. Jurnal Ilmu Ternak. 17(1):40-46.

Bell DD and WD Weaver Jr. 2002. Comercial Chicken Meat and Egg Production 5 th Edition. Springer Science and Business Medial Inc. New York.

Chamdi AN. 2005. Karakteristik sumberdaya genetik ternak sapi bali (Bos-bibos banteng) dan alternatif pola konservasinya. Jurnal Biodiversitas. 6(1):70-75. 
Depison. 2010. Performans anak hasil persilangan induk sapi bali dengan beberapa bangsa pejantan di Kabupaten Batanghari Provinsi Jambi. Jurnal Agripet. 10(1):37-41.

Hikmawaty, Gunawan A, Noor RR dan Jakaria. 2014. Identifikasi ukuran tubuh dan bentuk tubuh sapi bali di beberapa pusat pembibitan melalui pendekatan Analisis Komponen Utama. Jurnal Ilmu Produksi dan Teknologi Hasil Peternakan. 02(1):231-237.

Hummairah R, Hamdan dan Daulay AH. 2016. Identifikasi morfometriks dan jarak genetik ayam kampung (Domesticated chicken) di Kabupaten Batubara. Jurnal Peternakan Integratif. 03(03):329-343.

Inggriani $\mathrm{K}$, Tethool AN dan Lumatauw S. 2020. Pengaruh ekstrak sarang semut (Myrmecodia $\mathrm{Sp}$ ) dalam pengencer ringer laktat terhadap abnormalitas dan viabilitas spermatozoa ayam Kampung (Gallus gallus). Jurnal Ilmu Peternakan dan Veteriner Tropis. 10(1):1-7.

Kurnia Y. 2011. Morfometrik Ayam Sentul, Kampung dan Kedu pada Fase Pertumbuhan dari Umur 1-12 Minggu. Skripsi. Institut Pertanian Bogor. Bogor.

Nataamijaya AG. 2010. Pengembangan potensi ayam lokal untuk menunjang peningkatan kesejahteraan petani. Jurnal Litbang Pertanian. 29(04):131-138

Nei M. 1987. Molecular Evolutionary Genetics. Columbia University Press. New York.

Pinem U, Hamdan dan Hanafi ND. 2015. Estimasi jarak genetik dan faktor peubah pembeda rumpun kelinci melalui analisis morfometrik. Jurnal Peternakan Integratif. 02(3): 264-286.

Putri ABSRN, Gushairiyanto dan Depison. 2020. Bobot badan dan karaktristik morfometrik beberapa galur ayam lokal. Jurnal Ilmu dan Teknologi Peternakan Tropis. 7(3):256-263

Rajab dan Papilaya BJ. 2012. Sifat kuantitatif ayam kampung lokal pada pemeliharaan tradisional. Jurnal Ilmu Ternak dan Tanaman. 2(2):61-64.

Rangkuti NA, Hamdan dan Daulay AH. 2016. Identifikasi morfometriks dan jarak genetik ayam kampung di Labuhanbatu Selatan. Jurnal Peternakan Integratif. 3(1): 96-119.

Subekti K dan Arlina F. 2011. Karakteristik genetik eksternal ayam kampung di Kecamatan Sungai Pagu Kabupaten Solok Selatan. Jurnal Ilmiah Ilmu-Ilmu Peternakan. 19(2): 74-86.

Tamura K, Stecher G, Peterson D, Filipski A, and Kumar S. 2013. MEGA6: molecular evolutionary genetics analysis version 6.0. Molecular Biology and Evolution. 30(12): 2725-2729.

Triyanto. 2009. Pengenalan Minitab. Program Studi Pendidikan Matematika. Universitas Sebelas Maret. Surakarta.

Urfa S, Indijani H dan Tanwiriah W. 2017. Model kurva pertumbuhan ayam kampung unggul balitnak (KUB) umur 0-12 minggu. Jurnal Ilmu Ternak. 17(1):59-66. 